\title{
Q fever outbreak in the village of Noćaj, Srem county, Vojvodina province, Serbia, January to February 2012
}

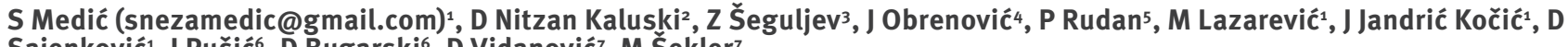

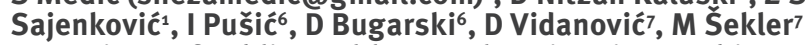

1. Institute of Public Health Sremska Mitrovica, Serbia

2. World Health Organization, Country Office in Serbia

3. Institute of Public Health of Vojvodina, Novi Sad, Serbia

4. Institute of Public Health of Serbia, Belgrade, Serbia

5. Institute of Public Health, Zrenjanin, Serbia

6. Veterinary Scientific Institute, Novi Sad, Serbia

7. Veterinary Specialized Institute Kraljevo, Serbia

Citation style for this article:

Medić S, Nitzan Kaluski D, Šeguljev Z, Obrenović J, Rudan P, Lazarević M, Jandrić Kočić J, Sajenković D, Pušić I, Bugarski D, Vidanović D, Šekler M. Q fever outbreak in the village of Noćaj, Srem county, Vojvodina province, Serbia, January to February 2012. Euro Surveill. 2012;17(15):pii=20143. Available online: http://www. eurosurveillance.org/ViewArticle.aspx?Articleld=20143

Article submitted on 26 March 2012/ published on 12 April 2012

From 27 January to 10 February 2012, a total of 43 cases of $Q$ fever were notified in the village of Noćaj, Srem county, Autonomous Province of Vojvodina, Republic of Serbia. Q fever was laboratory confirmed in 37 notified cases. Alhough, the outbreak is considered over, the outbreak investigation is still ongoing in order to identify aetiologic factors relevant for this outbreak.

On 27 January 2012 after 10 patients were hospitalised with atypical pneumonia, an outbreak of $Q$ fever was discovered in Srem county, Vojvodina province, Serbia. Laboratory testing of some of the first patients for pathogens such as Coxiella burnetii, Chlamydia pneumoniae, Mycoplasma pneumoniae, influenza A and B, parainfluenza, and respiratory syncytial virus had all resulted negative, except for $C$. burnetii.

Between 27 January and 10 February, 2012, 43 cases of $Q$ fever were reported. The majority of patients $(n=41)$ were residents of Noćaj, a village with 2,120 inhabitants located in the vicinity of the city of Sremska Mitovica (Srem county) near the border between Serbia and Bosnia and Herzegovina. The attack rate in this period was $2 \%$.

Hereby we describe the preliminary results of the ongoing outbreak investigations started on 30 January 2012, by the Center for Disease Control and Prevention of the Institute of Public Health, Sremska Mitrovica. The investigation was assisted by the World Health Organization (WHO), Regional Office for Europe.

\section{Epidemiological investigation}

Specific notification criteria and case definitions adapted to the current situation were applied. A probable case of $\mathrm{Q}$ fever, according to the European Union criteria, which are used in Serbia [1], was not relevant in this investigation because the source of the current outbreak was not yet identified, and no epidemiological link could be established.

A 'clinical case' was defined as having acute fever and one or more of the following: rigors, severe retrobulbar headache, acute hepatitis, pneumonia, or elevated liver enzymes' levels with onset of illness between 20 January and 10 February, and no other likely cause for illness in a patient who either lived or visited Noćaj in the period from 1 to 20 January, 2012. The risk period for exposure was estimated considering an average incubation period of 20 days [2] and time distribution of cases.

A 'clinical case" who had not been serologically tested was defined as a possible case of $Q$ fever.

A laboratory-confirmed case of acute $Q$ fever was defined as a 'clinical case' with serologic evidence of a positive IgM and/or IgG antibody result to phase II antigen $C$. burnetii, by enzyme-linked immunosorbent assay (ELISA). The results were interpreted in line with the manufacturer's guidance as follows: <9, negative; 9-11, equivocal; >11, positive (ELISA, NovaLisa). Paired sera samples tested at least two weeks appart were taken for four patients for whom the result of the first sera tests were equivocal or negative (two sera samples were positive after the second test).

All sera samples were tested in the Reference Laboratory for Q fever, Institute of Public Health, Zrenjanin, Serbia. Of 43 notified cases, 37 were laboratory confirmed and the rest were classified as possible cases. All laboratory-confirmed cases were classified as acute $Q$ fever cases. All cases of acute $Q$ fever with known preconditions for chronic disease were reffered for laboratory follow-up in periods of three, six and twelve months after onset of illness, in order to detect 
the development of chronic $Q$ fever [3]. The majority of cases $(n=41)$ reported illness onset between 20 January and 1 February 2012 (Figure).

\section{FIGURE}

Cases of Q fever by date of symptom onset, Noćaj, Sremska Mitrovica, Serbia, 20 January-10 February $2012(n=43)$

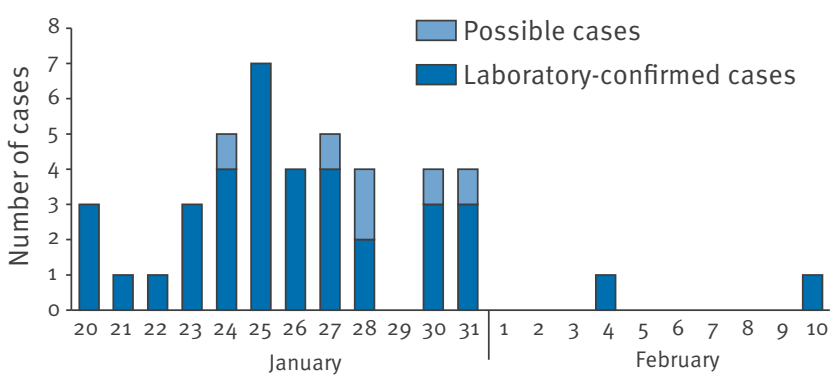

Date of disease onset, 2012

The male to female ratio of cases was 3.6:1. The mean age \pm standard deviation was $35.65 \pm 14.3$ years with the age distribution of cases ranging from 14 to 75 years. Data about the age and sex of cases rates are shown in Table 1.

Thirty-six of 43 registered cases were diagnosed with atypical pneumonia by chest $\mathrm{X}$-ray. Sixteen of them were hospitalised. All patients had good outcomes without sequelae. The clinical features of $Q$ fever in this outbreak are presented in Table 2.

During the epidemiological investigation in the village households, all present family members were interviewed about symptoms of $Q$ fever and possible preconditions for chronic $Q$ fever. Efforts were made to conduct laboratory testing, in order to detect recent $Q$ fever infection in asymptomatic people, with known preconditions for chronic $Q$ fever or at risk for complications, like pregnant women $(n=10)$ and newborns $(n=2)$, people with heart valvular diseases $(n=1)$ or immunosupression $(n=2)$. Also exposed healthcare workers $(n=9)$ were tested. The testing was done by ELISA in order to detect a $C$. burnetii specific antibody response (IgG or IgM phase II), as previously described. By 26 March, eight additional cases of asymptomatic $Q$ fever were discovered including three pregnant women, four exposed healthcare workers and one child with undefined symptoms. They were all refered to infectious disease specialists for review.

In exploratory interviews taken between 30 January and 16 February, 28 of 43 patients denied direct contact with livestock, although most of them own livestock in their households. In Serbia, reporting on aborted pregnancy in domestic animals is mandatory and requires a standard number of tests including tests for $C$. burnetii. However in the previous few months, local farmers and veterinary services in Noćaj had not observed such cases.

Only two patients in the current outbreak were not residents of Noćaj. They visited their relatives in Noćaj for a few hours each on different days (8 and 16 January). The time of the visits to Noćaj is compatibile with the incubation period and onset of disease in these particular patients. Overall 30 of 43 patients mentioned that they had visited a football tournament in the village school sport hall, from 4 to 7 January, 2012.

\section{Environmental investigation and results}

As the large number of cases in a small area was suggestive of a point source, smear samples were taken from heating ventilators, seats and the floor of the sport hall. DNA extraction from swabs was performed using QIAamp DNA Mini Kit (Qiagen, Germany) in the Veterinary Specialized Institute Kraljevo, Serbia. Two polymerase chain reaction (PCR) protocols were used for molecular detection of $C$. burnetii: The Real-Time PCR protocol published by Klee et al. [4] and the PCR protocol published by Berri et al. [5] The PCR assays for C. burnetii were all negative.

The Veterinary Scientific Institute, Novi Sad, conducted an epizootiologic investigation in the households of patients and their neighbours by order of the Republic Veterinary Inspectorate. Of 207 tested sheeps, goats and cattle, only one seropositive sheep in the village was found. Although seropositive, the vaginal swab sample of this seropositive sheep analysed by PCR was negative. Interestingly, this seropositive sheep was detected in a particular household in which two of seven human cases were registered during an outbreak of $Q$ fever in Noćaj in 2009.

\section{Epidemiological situation in Serbia}

Q fever, a zoonosis distributed worldwide, was recognised as a specific disease in 1937 [6], and is caused by

TABLE 1

Cases of Q fever, by age group and sex, Noćaj, Sremska Mitovica, Serbia, 20 January-10 February 2012 (n=43)

\begin{tabular}{|l|c|c|c|c|c|c|c|c|}
\hline \multirow{2}{*}{ Cases } & \multicolumn{9}{|c|}{ Age groups in years } & \multirow{2}{*}{ Total number of cases } \\
\cline { 2 - 10 } & 115 & $15-24$ & $25-34$ & $35-44$ & $45-54$ & $55-64$ & $>65$ & 34 \\
\hline Number of male cases & 1 & 7 & 12 & 5 & 7 & 2 & 0 & 9 \\
\hline Number of female cases & 0 & 1 & 4 & 1 & 1 & 0 & 2 & $\mathbf{2}$ \\
\hline Total number of cases & $\mathbf{1}$ & $\mathbf{8}$ & $\mathbf{1 6}$ & $\mathbf{6}$ & $\mathbf{8}$ & $\mathbf{2}$ & $\mathbf{2}$ & $\mathbf{4 3}$ \\
\hline
\end{tabular}


C. burnetii. A wide range of animals serves as a natural reservoir for the pathogen [7]. Inhaling aerosols that are contaminated by $C$. burnetii is the most frequent route of transmission in large human outbreaks $[8,9]$. Q fever outbreaks are regulary reported thoughout Europe as well as in other parts of the world [10].

In Serbia, Q fever is a notifiable disease since 1966. Notification of $Q$ fever is made on the basis of clinical diagnosis, epidemiological link and laboratory confirmation. During the last 14 years notification is based on European Union case-definition criteria in the absence of criteria adopted at the national level [1].

The Autonomous Province of Vojvodina, (Northern Province of Serbia) including Srem county is considered as an endemic region for $Q$ fever. The latest seroepidemiological investigation of $Q$ fever, which was conducted in 1985 and included 5,599 persons (representing $0.5 \%$ of the adult population of Vojvodina aged between 19 and 59 years), revealed a seroprevalence of C. burnetii antibodies of $9.3 \%$ [11]. In the period from 2002 to 2011, the incidence rate of Q fever in Vojvodina varied between $0.1-2.3$ per 100,000 population. The incidence rate in Srem county varied between o and 2.1

\section{TABLE 2}

Clinical features in cases of Q fever, Noćaj, Sremska Mitovica, Serbia, 20 January-10 February $2012(n=43)$

\begin{tabular}{|l|c|}
\hline Clinical features & Number of cases \\
\hline Fever $\left(\geq 38^{\circ} \mathrm{C}\right)$ & 35 \\
\hline Headache & 27 \\
\hline Chills, shivers & 22 \\
\hline Pneumonia & 20 \\
\hline Muscle ache & 19 \\
\hline Cough & 13 \\
\hline Discomfort & 4 \\
\hline
\end{tabular}

per 100,000 population, with two outbreaks reported in 2009 [12] and 2011 (unpublished data). In the 2009 outbreak, seven human cases were notified in the village of Noćaj. Considering the high rate of mild cases and non-specific symptoms of $Q$ fever [10], it is estimated that the actual incidences might be higher than presented above.

\section{Outbreak control measures}

The Center for Disease Control and Prevention of the Institute of Public Health Sremska Mitrovica proposed to the management of the Noćaj elementary school to improve hygiene and proceed to a desinfection of the sport hall, and these measures were applied by order of the Provincial Sanitary Inspectorate.

General practitioners in the area and the nearest healthcare centre in Bosnia and Herzegovina were informed about the outbreak in order to make sure that any new arising cases of $Q$ fever would be notified. All authorised institutions were informed, including the
WHO, Regional Office for Europe following obligations included in the International Health Regulations (IHR) [13].

Efficient data sharing with the veterinary services was ensured in order to identify potential source(s) of the outbreak and to conduct veterinary control measures. Livestock trading, slaughter and use of unpasteurised milk and products from unpasteurised milk were temporarely prohibited in the investigated households until the serology results of tested animals were obtained.

Exclusion of blood donors (rather than screening) from the affected region was done. Health promotion campaigns to educate citizens on how to prevent possible $Q$ fever infection took place in the village in the form of interviews, lectures and the delivering of information leaflets. Appropriate hygiene practices when dealing with livestock by-products of birth and manure and safe procedures for clothing and footwear were the key messages in the health education campaign for farmers. People at high risk for severe $Q$ fever infection or complications were advised not to visit or stay in the livestock holding areas or barns.

In order to investigate potential factors for airborne spread of the bacteria, official meteorological data were analysed. Epidemiological reports were updated and published on the website of the Institute of Public Health of Sremska Mitrovica providing authoritative and accurate informations regarding the outbreak and reducing fear and panic in the village and area.

In order to prevent hospital acquired C. burnetii infections among healthcare workers and patients, the commission for the prevention of hospital infections in the general hospital Sremska Mitrovica proposed implementation of enhanced standard precautionary measures, such as monitoring compliance with hand hygiene, the use of gloves for contact with blood or body fluids, excretions and secretions, as well as anticipating the need for use of personal protective equipment (gowns, masks) according to the patient condition and type of procedure.

\section{Discussion and conclusions}

Considering the unusual high rate of hospitalisations and atypical pneumonia in this outbreak, we can assume that the number of cases is far higher than reported. The predominance of male sex among patients is not surprising, because the infection may be asymptomatic in $60 \%$ of $Q$ fever infections, especially among women and children aged 15 years and younger [14-16].

Although a single animal source can cause many human Q fever cases [17], compared to 2009, the larger geographic area in which cases occurred in 2012 may indicate a multiple sources or possible airborne spread of $C$. burnetii. The low annual number of cases 
of $\mathrm{Q}$ fever in Noćaj registered during past few decades was due to direct contact with animal placenta and/or birth products. The sudden and unusual acute presentation of the large outbreak in the current situation, required the consideration of other routes of $Q$ fever infection. Although many cases in the village of Noćaj had attended the same football tournament in a school sport hall, the environmental investigation yielded negative results. Moreover, there were no registered cases of $\mathrm{Q}$ fever among residents of other villages who attended the tournament, nor among school children/ staff where the tournament took place, which argues against the school sporthall as being the source of the outbreak. Until now, no common exposure has been identified among patients who did not attend the football tournament.

The data obtained from the epidemiological investigation were not indicative of a foodborne route of infection. The presumable route of infection in this outbreak is airborne by inhalation of contaminated dust and aerosol in the period around the orthodox Christmas. During January the weather in Noćaj was unusually dry and windy so the conditions to transmit $C$. burnetii were present. The heavy snowfall during February possibly reduced the further spread of this outbreak and limited its duration. We cannot rule out other possible causes via direct contact with livestock or by other possible exposures. Epidemiological investigation of infection sources and routes of transmission is ongoing. With this report, we would like to inform of this outbreak and raise awareness in neighbouring countries.
References

1. European Commission. Commission decision of 28 April 2008 amending Decision 2002/253/EC laying down case definitions for reporting communicable diseases to the Community network under Decision No 2119/98/EC of the European Parliament and of the Council (reference number C(2008) 1589) $2008 / 427 / E C$. Official Journal of the European Union. Luxembourg: Publications Office of the European Union. 18.6.2008 L 159/65. Available from: http://eur-lex.europa.eu/ LexUriServ/LexUriServ.do?uri=0J:L:2008:159:0046:0090:EN: PDF

2. Fournier PE, Marrie TJ, Raoult D. Diagnosis of $Q$ fever. J Clin Microbiol. 1998;36(7):1823-34.

3. Van der Hoek W, Versteeg B, Meekelenkamp JC, Renders NH, Leenders AC, Weers-Pothoff I, et al. Follow-up of 686 patients with acute $Q$ fever and detection of chronic infection. Clin Infect Dis. 2011;52(12):1431-6.

4. Klee SR, Tyczka J, Ellerbrok H, Franz T, Linke S, Baljer G, et al. Highly sensitive real-time PCR for specific detection and quantification of Coxiella burnetii. BMC Microbiol. 2006;6:2.

5. Berri M, Laroucau K, Rodolakis A. The detection of Coxiella burnetii from ovine genital swabs, milk and fecal samples by the use of a single touchdown polymerase chain reaction. Vet Microbiol. 2000;72(3-4):285-93.

6. Derrick EH. Q fever, a new fever entity: clinical features, diagnosis and laboratory investigation. Med J Aust. 1937;2:281-99.

7. Maurin M, Raoult D. Q fever. Clin Microbiol Rev. 1999;12(4):518-53.

8. Schimmer B, Dijkstra F, Vellema P, Schneeberger PM, Hackert $\mathrm{V}$, ter Schegget R, et al. Sustained intensive transmission of $Q$ fever in the south of the Netherlands, 2009. Euro Surveill. 2009;14(19):pii=19210. Available from: http://www. eurosurveillance.org/ViewArticle.aspx?Articleld=19210

9. Forland F, De Carvalho Gomes H, Nokleby H, Escriva A, Coulombier D, Giesecke J, et al. Applicability of evidence-based practice in public health: risk assessment on $\mathrm{Q}$ fever under an ongoing outbreak. Euro Surveill. 2012;17(3): pii=20060. Available from: http://www.eurosurveillance.org/ViewArticle. aspx?Articleld $=20060$

10. De Valk H. Q fever: new insights, still many queries. Euro Surveill. 2012;17(3):pii=20062. Available from: http://www. eurosurveillance.org/ViewArticle.aspx?Articleld=20062

11. Šeguljev Z, Vuković B, Stefanović S, Stošić Ž, Samardžić V, Bačić M. Seroepidemiological investigation of Q fever in Vojvodina (Yugoslavia). Giorn Mal Inf Parass. 1990;42(7):424-26.

12. Institute of public health of Vojvodina. [Communicable diseases in Autonomous Province of Vojvodina, 2009]. Novi Sad: Institute of public health of Vojvodina;2010. 4. p.137-8. Serbian.

13. World Health Organization (WHO). International Health Regulations (2005) (IHR). Geneva: WHO. [Accessed $08 \mathrm{Apr}$ 2012]. Available from: http://www.who.int/ihr/en/

14. Raoult D, Marrie T, Mege J. Natural history and pathophysiology of Q fever. Lancet Infect Dis. 2005;5(4):219-26.

15. Leone M, Honstettre A, Lepidi H, Capo C, Bayard F, Raoult D, et al. Effect of sex on Coxiella burnetii infection: protective role of 17beta-estradiol. J Infect Dis. 2004;189(2):339-45.

16. Maltezou HC, Raoult D. Q fever in children. Lancet Infect Dis. 2002;2(11): 686-91.

17. Porten K, Rissland J, Tigges A, Broll S, Hopp W, Lunemann M, et al. A super-spreading ewe infects hundreds with $Q$ fever at a farmers' market in Germany. BMC Infect Dis. 2006;6:147. 